

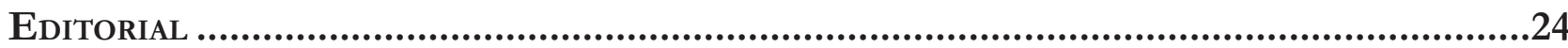

O Direito na fronteira da razão: Psicologia, neurociência e economia comportamental................... 24 Patrícia Perrone Campos Mello e Sergio Nojiri

I. NeURodireito: COGNIÇão, EMOÇÃo, JUÍZOS MORAIS E CIÊNCIA ..........................................26

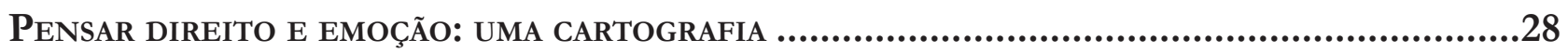

Nevita Maria Pessoa de Aquino Franca Luna

Neurodireito: o início, o fim E O MEIO

Carlos Marden e Leonardo Martins Wykrota

ENSAIO JURÍDICO SOBRE A RACIONALIDADE HUMANA: MAIORES, CAPAZES E IRRACIONAIS

André Perin Schmidt Neto e Eugênio Facchini Neto

DIVERGÊNCIAS DE PRINCÍPIO: ARGUMENTOS JURÍDICOS E MORAIS EM UM CENÁRIO DE DESACORDOS SOCIAIS

André Matos de Almeida Oliveira, Pâmela de Rezende Côrtes e Leonardo Martins Wykrota

CONSILIÊNCIA E A POSSIBILIDADE DO NEURODIREITO: DA DESCONFIANÇA À RECONCILIAÇÃO DISCIPLINAR.....

Thaís de Bessa Gontijo de Oliveira e Renato César Cardoso

MODELOS DE MORALIDADE

Molly J. Crockett

A INFELIZ BUSCA POR FELICIDADE No DiREITo

Úrsula Simões da Costa Cunha Vasconcellost, Noel Struchiner e Ivar Hannikainen

Além da liberdade: PersPeCtivas Em Nietzsche.

Lucas Costa de Oliveira

A mediaÇão de CONFlitos SOb a PERSPECTIVA do DESENVOLVIMENTO HUMANO: AS CONTRIBUIÇÕES DA PSICOLOGIA POSITIVA

Simone de Biazzi Ávila Batista da Silveira e Deise Brião Ferraz

Neuroimagiologia e aValiação de ResPonsabilidade

Nicole A. Vincent 
ANÁLISE CRÍTICA DA ORIENTAÇÃO DE CIDADÃOS COMO MÉTODO PARA OTIMIZAR DECISÕES PÚBLICAS POR MEIO DA TÉCNICA NUDGE.

Luciana Cristina Souza, Karen Tobias França Ramos e Sônia Carolina Romão Viana Perdigão

Políticas públicas e o deVer de monitoramento: “LEVANdo os Direitos A SÉrio". .252 Ana Paula de Barcellos

Nudges E POLÍticas PÚblicas: uM MECANISMO DE COMBATE AO TRABALHO EM CONDIÇÃo ANÁLOGA À DE ESCRAVO .267

Amanda Carolina Souza Silva, Débhora Renata Nunes Rodrigues e Saul Duarte Tibaldi

REDUZINDO A TRIBUTAÇÃO COGNITIVA: LIÇÕES COMPORTAMENTAIS PARA A DIMINUIÇÃO DOS EFEITOS PSICOLÓGICOS ADVERSOS DA POBREZA.............................................................288 Leandro Novais e Silva, Luiz Felipe Drummond Teixeira, Gabriel Salgueiro Soares e Otávio Augusto Andrade Santos

Políticas PÚBLICAS EM SUICÍDIO: DO PATERNALISMO CLÁSSICO AO PATERNALISMO LIBERTÁRIO E NUDGING

Davi de Paiva Costa Tangerino, Gabriel Cabral e Henrique Olive

Nudges COMO POLÍticA PÚbliCA PARA AUMENTAR O ESCASSO NÚMERO DE DOADORES DE ÓRGÃos PARA TRANSPLANTE

Roberta Marina Cioatto e Adriana de Alencar Gomes Pinheiro

Os PROGRAMAS DE INTEGRIDADE PARA CONTRATAÇÃO COM A ADMINISTRAÇÃO PÚBLICA ESTADUAL: NUDGE OU OBRIGAÇÃo LEGAL? UM OLHAR SOBRE AS DUAS PERSPECTIVAS .386

Cíntia Muniz Rebouças de Alencar Araripe e Raquel Cavalcanti Ramos Machado

Paternalismo libertário e Proteção JURídica do AMbiente: POR QUe PROTEger o AMBIENTE TAMBÉM DEVE SER PROTEGER AS LIBERDADES?

Mariana Carvalho Victor Coelho e Patryck de Araujo Ayala

Políticas PÚblicas baseadas EM EVIdÊNCIAS COMPORTAMENTAIS: REFLEXões A PARTIR do Projeto de Lei 488/2017 do Senado

Pâmela de Rezende Côrtes, André Matos de Almeida Oliveira e Fabiano Teodoro de Rezende Lara

III. ECONOMIA COMPORTAMENTAL: VIESES COGNITIVOS E POLÍTICAS PÚBLICAS .455

ECONOMIA COMPORTAMENTAL E DIREITO: A RACIONALIDADE EM MUDANÇA Marcia Carla Pereira Ribeiro e Victor Hugo Domingues

VIESES COGNITIVOS E DESENHO DE POLÍTICAS PÚBLICAS 
A neurociênCia da moralidade na tomada de DeCisões Jurídicas Complexas e No DESENHO DE POLÍTICAS PÚBLICAS

Erik Navarro Wolkart

Desvio de CARÁter ou SIMPLESMENTE HUMANO? ECONOMIA COMPORTAMENTAL APLICADA AO COMPORTAMENTO DESONESTO

Diana Orghian, Gabriel Cabral, André Pinto e Alessandra Fontana

Políticas Públicas e a ConcretizaÇão de direitos sociais: TOMAdA DE DECisão, ARQUITETURA DE ESCOLHAS E EFETIVIDADE

Ana Elizabeth Neirão Reymão e Ricardo dos Santos Caçapietra

BEHAVIORAL ECONOMICS E DIREITO DO CONSUMIDOR: NOVAS PERSPECTIVAS PARA O ENFRENTAMENTO DO SUPERENDIVIDAMENTO .568

Samir Alves Daura

A EDUCAÇÃo FORMAL PARA O CONSUMO É GARANTIA PARA UMA PRESENÇA REFLETIDA DO CONSUMIDOR NO MERCADO? UMA ANÁLISE COM BASE NA BEHAVIORAL LAW AND ECONOMICS (ECONOMIA COMPORTAMENTAL) 600

Marcia Carla Pereira Ribeiro e Edson Mitsuo Tiujo

LIBET, DETERMINISMO E CONSUMO: AS INFLUÊNCIAS DO MARKETING E A RELEVÂNCIA DA DELIBERAÇÃo CONSCIENTE NA SUPERAÇÃo CONDICIONAL DE HÁBITOS DE CONSUMO PERIGOSOS616 Émilien Vilas Boas Reis e Leonardo Cordeiro de Gusmão

CiÊNCIA DO DIREITO TRIBUTÁRIO, ECONOMIA COMPORTAMENTAL E EXTRAFISCALIDADE. .640 Hugo de Brito Machado Segundo

IV. CoMportamento JUdiCiAL: INFLUÊNCIA DE FATORES EXTRAJURÍDicos .660

FATORES METAPROCESSUAIS E SUAS INFLUÊNCIAS PARA A FORMAÇÃo DA DECISÃo JUDICIAL .662 Rogério Roberto Gonçalves de Abreu, Lúcio Grassi de Gouveia e Virgínia Colares

“A VIDA COMO ELA É": COMPORTAMENTO ESTRATÉGICO NAS CORTES Patrícia Perrone Campos Mello

A COMPOSIÇÃo do ÓRGão COLEGIAdo E SEUS EFEITOS NA TOMADA DE DECISÃo .720 André Garcia Leão Reis Valadares

Das 11 ilhas ao centro do arquipélago: os superpoderes do Presidente do STF DURANTE O RECESSO JUDICIAL E FÉRIAS .741 José Mário Wanderley Gomes Neto e Flávia Danielle Santiago Lima 
RAZÃo, EMOÇÃo E DELIBERAÇÃO: AS ADEQUAÇÕES REgIMENTAIS do SUPERIOR TribUNAL DE JUSTIÇA PARA A FORMAÇÃo DE PRECEDENTES EFICAZES

Peter Panutto e Lana Olivi Chaim

Heurística de ancoragem e fiXaÇÃo de danos morais em JUizados especiais Cíveis no Rio DE JANEIRO: UMA NOVA ANÁLISE 778

Fernando Leal e Leandro Molhano Ribeiro

LA PROTECCIÓN DE LOS DERECHOS POLÍTICOS FRENTE A LAS FUNCIONES DISCIPLINARIAS DE LAS AUTORIDADES ADMINISTRATIVAS: SUBSIDIARIEDAD Y DEFERENCIA EN EL SISTEMA INTERAMERICANO DE DERECHOS HUMANOS Jorge Ernesto Roa Roa

V. A influênCia do gÊNERo no PROCESSO DECisório JUdiCial

Como os Juízes decidem os Casos de estupro? ANALISANDo SENTENÇAS SOb A PERSPECTIVA DE VIESES E ESTEREÓTIPOS DE GÊNERO 826 Gabriela Perissinotto de Almeida e Sérgio Nojiri

GÊNERO E COMPORTAMENTO JUDICIAL NO SUPREMO TRIBUNAL FEDERAL: OS MINISTROS CONFIAM MENOS EM RELATORAS MULHERES?

Juliana Cesario Alvim Gomes, Rafaela Nogueira e Diego Werneck Arguelhes

Hércules, Hermes e a Pequena Sereia: uma reflexão sobre estereótipos de gênero, SUBPRESENTAÇÃo DAS MULHERES NOS TRIBUNAIS E (I)LEGITIMIDADE DEMOCRÁTICA DO PODER JUDICIÁRIO. .878 Jane Reis Gonçalves Pereira e Renan Medeiros de Oliveira

Prisão Cautelar de gestantes: análise do Fundamento filosófico da decisão do Habeas CoRpus N. 143.641 912

Artur César Souza e Giovania Tatibana de Souza

VI. Neurodireito APlicado ao direito E Ao Processo PENAL....................................926

CÉREbros QUe PUNEM: UMA REVISÃo CRÍTICA DA NEURoCIÊNCIA DA PUNIÇÃo .....................928 Ricardo de Lins e Horta

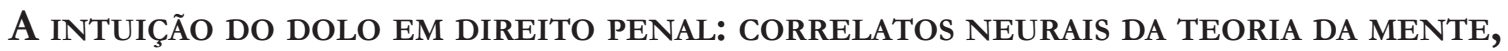
RACIOCÍNIO INDUTIVO E A GARANTIA DA CONVICÇÃO JUSTIFICADA. .946 Thiago Dias de Matos Diniz e Renato César Cardoso

As COMUNIDADES EPISTÊMICAS PENAIS E A PRODUÇÃo LEGISLATIVA EM MATÉRIA CRIMINAL..... 961 Stéphane Enguéléguélé 
DELINQUÊNCIA JUVENIL: RELAÇÕES ENTRE DESENVOLVIMENTO, FUNÇÕES EXECUTIVAS E COMPORTAMENTO SOCIAL NA ADOLESCÊNCIA .

André Vilela Komatsu, Rafaelle CS Costa e Marina Rezende Bazon

Límites TEMPORALES A LAS PENAS PRIVATIVAS DE LIBERTAD ATENDIENDO AL DESARROLLO PSICOSOCIAL.

Silvio Cuneo Nash

NEURolaw E AS PERSPECTIVAS PARA UMA ANÁLISE OBJETIVA DO COMPORTAMENTO SUGESTIONADO: REPERCUSSÃO DAS FALSAS MEMÓRIAS NA ESFERA PENAL

Mariana Dionísio de Andrade, Marina Andrade Cartaxo e Rafael Gonçalves Mota

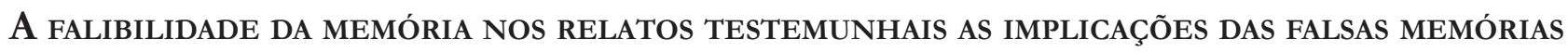
NO CONTEXTO DOS CRIMES CONTRA A DIGNIDADE SEXUAL

Caroline Navas Viana

A (IR)REPETIBILIDADE dA PROVA PENAL DEPENDENTE DA MEMÓRIA: UMA DisCUSSÃo COM BASE NA PSICOLOGIA DO TESTEMUNHO. 1058

William Weber Cecconello, Gustavo Noronha de Avila e Lilian Milnitsky Stein 


\title{
Os programas de integridade para contratação com a administração pública estadual: nudge ou obrigação legal? Um olhar sobre as duas perspectivas*
}

\section{Integrity programs for hiring with the state public administration: nudge or legal?}

\author{
Cíntia Muniz Rebouças de Alencar Araripe** \\ Raquel Cavalcanti Ramos Machado***
}

\section{Resumo}

O relacionamento do setor privado com a Administração Pública tem passado por profundas transformações, sendo uma delas o incentivo dos Poderes à implementação de programas de integridade nas empresas. Por serem custosos e envolverem, no mais das vezes, transformação de cultura, tais programas vinham sendo implantados tão-somente por imperativos de mercado, figurando-se de extrema valia uma política pública baseada em nudges. Sucede que alguns Estados têm exigido os programas de integridade para contratação com a sua Administração. Tem-se por objetivo geral averiguar como seria uma política pública baseada em nudges e outra em exigências legais, confrontando as duas técnicas, inclusive, sob a ótica de sua constitucionalidade e oportunidade. Como objetivos específicos, destacam-se: a) compreender a política pública baseada em nudges; b) examinar a constitucionalidade e a oportunidade da exigência, por lei estadual, de programas de integridade para contratar com a Administração; c) debater ambas as técnicas, contrapondo os argumentos. Utilizar-se-á de metodologia de cunho dedutivo teórico, prescritivo e dialético. Remonta a outubro/2017 a lei estadual que, primeiramente, veio obrigar as empresas a implementarem tais programas, sendo a discussão ainda incipiente e, portanto, oportuna e atual. Apesar de o STF não ter sido instado a se manifestar sobre a exigência, por lei estadual, de programas de integridade na contratação com a Administração Pública, a dicção que se extrai dos seus julgados é pela sua inconstitucionalidade. Na doutrina, não há consenso sequer sobre a sua oportunidade. O ordenamento jurídico brasileiro, entretanto, dispõe de ferramentas outras, menos controversas, das quais se pode fazer uso.

Palavras-chave: Política pública. Contratação. Administração Pública. Nudge. Obrigatoriedade. Programas de integridade.

\section{Abstract}

The relationship between the private sector and the public administration has undergone profound changes, one of them being the incentive of 
the three branches of Government to implement integrity programs in companies. Because they are costly and they involve, more often than not, the transformation of culture, such programs are only being implemented by market imperatives. A nudge-based public policy is extremely valuable. It so happens that some states have required integrity programs for hiring with their Administration. The general objective of this article is to find out how a public policy based on nudges would be and also another on legal requirements, confronting both techniques, including the point of view of its constitutionality and opportunity. Specific objectives include: a) understanding the public policy based on nudges; b) to examine the constitutionality and the opportunity of the state's requirement of integrity programs to contract with the Administration; c) discuss both techniques. It will use theoretical, prescriptive and dialectical deductive methodology. It goes back to October/2017 the state law that first came to compel companies to implement such programs, so the discussion is still incipient and therefore timely and current. Although the Supreme Court has not been asked to express its view on the requirement by state law for integrity programs in contracting with the Public Administration, it has decided about similar obligations and the understanding is that it's unconstitutional. In doctrine, there is no consensus at all about its opportunity. The Brazilian legal system, however, has other, less controversial, tools that can be used.

Keywords: Public policy. Contracts. Public administration. Nudge. Integrity programs.

\section{INTRODUÇÃo}

Thaller e Sustein introduzem o nudge com a imagem de Carolyn, uma criativa diretora de alimentação das escolas de uma grande cidade, e de seu amigo Adam, um consultor de gestão com larga experiência em cadeias de supermercados e conhecimento em estatísticas. Intrigados com a perspectiva de que a ordem ou o modo como dispostos os produtos poderia vir a influir na escolha dos alunos, Carolyn e Adam decidiram realizar nas cafeterias das escolas por ela geridas um experimento. Foram dadas aos diretores instruções específicas de como organizar os produtos à venda nas suas cafeterias. Nalgumas delas, as batatas fritas foram colocadas ao alcance dos olhos; em outras, os palitos de cenoura. As sobremesas foram postas no começo da fila nalguns locais, enquanto, em outros, foram colocadas em local separado. E assim foi feito com variados produtos alimentícios. Fato é que Carolyn e Adam conseguiram acrescer ou reduzir em até $25 \%$ o consumo de alguns alimentos, sem alterar os preços e os produtos oferecidos no cardápio das cafeterias nem sequer proibir o consumo de um ou de outro, mas apenas e tão-somente com a organização dos alimentos de forma diferenciada, conferindo destaque a determinados produtos. Concluiu-se, assim, que os alunos poderiam ser influenciados com uma simples mudança de contexto. ${ }^{1}$ Isto é nudge. É interferir sutilmente no comportamento de outrem, sem fazer uso de proibições, restrições ou vultosos incentivos financeiros, respeitando, assim, a sua liberdade de escolha.

Nessa senda, pressupondo serem as pessoas, em sua maioria, homo sapiens e não homo economicus e que, ipso facto, não tomariam as melhores decisões em todo o tempo (ou, pelo menos, as melhores decisões que tomariam se quiçá fossem as circunstâncias diferentes), os autores passaram a defender o uso de nudges em numerosas ocasiões. Ter uma alimentação saudável, parar de fumar ou de apostar, fazer investimentos mais rentáveis, salvar para a aposentadoria etc. passaram a ser objeto dos mais variados nudges, prenunciados como respostas intuitivas e descomplicadas e, ao mesmo tempo, novadoras para velhos problemas.

Há longos anos, o Brasil passa por problemas relacionados à corrupção e isto tem repercutido nos contratos, concessões e parcerias firmados pelo setor público. A implantação de programas de integridade nas empresas - e na própria Administração Pública direta e indireta, diga-se de passagem — em muito colaboraria para o enfrentamento desse problema.

1 THALER, Richard H.; SUSTEIN, Cass R. Nudge: improving decisions about health, wealth, and happiness. New York: Penguin Books, 2009. p. 1-2. 
Os programas de integridade abrangem uma série de mecanismos de conformidade e de integridade, a serem continuamente disseminados na empresa/entidade pública e auditados, objetivando prevenir irregularidades, fraudes e atos de corrupção praticados contra a Administração Pública, sem que se olvide a detecção e a punição daqueles que, ainda assim, insistem na prática de tais atos.

Não obstante isso, a implantação de programas de integridade é custosa e, na maioria das vezes, envolve alteração de toda uma cultura, não somente da empresa, mas do próprio ramo em que atua. Daí a extrema valia de uma política pública baseada em nudges para encorajar as empresas que projetam contratos com a Administração Pública a instituírem tais programas. Sucede que alguns Estados têm transposto o nudge com a publicação de legislações que obrigam, a depender do tipo e do valor do objeto/ serviço, a implementação de programas de integridade por empresas que com ele pretendem contratar. Afinal, uma política pública que oriente o relacionamento entre os setores público e privado, incitando a instituição de programas de integridade pelas empresas, deve se basear em nudges ou fazer uso de exigências legais? Eis o dilema.

A doutrina, até o presente momento, não tem se debruçado sobre a questão. Aliás, a discussão sobre a integridade como mecanismo é, ainda, incipiente, tendo sido intensificada a partir de 2013, quando veio a lume a Lei no 12.846, intitulada Lei Anticorrupção. Ademais, data de outubro de 2017 a lei estadual que primeiro veio obrigar o setor privado a implementar programas de integridade. Deveras oportuna e atual, portanto, a discussão.

O artigo perpassará noções de nudge para, empós, ponderar se, ao encorajar as empresas privadas a implementar programas de compliance, o Poder Público estaria a praticar nudge. Em seguida, procura idear como seria uma política pública com esse escopo. É o que se pretende, a princípio, discutir.

$\mathrm{Na}$ sequência, pretende-se ir além do nudge com o exame da constitucionalidade e da oportunidade de algumas leis estaduais que têm obrigado a implementação de programas de integridade nas empresas que firmarem contratos com o Poder Público.

Por derradeiro e à luz do que foi constatado, discutir-se-á a questão da política pública que deve orientar o relacionamento entre a Administração Pública e aqueles que com ela pretendem contratar sob a ótica dos programas de integridade. Nada obstante a adoção desses programas em muito beneficiar o poder público e toda a sociedade — o que neste artigo não se discute, o ordenamento jurídico brasileiro dispõe de ferramentas outras (diferençadas do ato de pura e simplesmente exigir), menos controversas, das quais se pode fazer uso.

No que atine à metodologia, a definição de nudge e o devido enquadramento e desenho de uma política pública que incentive as empresas privadas a implementarem programas de integridade, utilizará o método dedutivo, inicialmente teórico e, posteriormente, prescritivo.

Quanto à análise da constitucionalidade e da oportunidade das leis estaduais que vieram obrigar a implementação desses programas com as empresas que vierem a contratar com as administrações públicas estaduais, far-se-á uso do método dedutivo teórico.

Por fim, o método dialético orientará o exame da política pública em questão com base nos argumentos dissonantes.

\section{TEORIA DO NUDGE NA ADOÇÃO DE PROGRAMAS DE INTEGRIDADE POR EMPRESAS QUE projetam contratos com a Administração Pública}

No ano de 1986, o Congresso norte-americano aprovou o Emergency Planning and Community Right-to-Know Act (EPCRA). Em resposta aos desastres ambientais que se sucederam em Bhopal, na Índia, e em Chernobil, na Ucrânia, e com o fito de atenuar a probabilidade de que símiles desastres ocorressem em território 
americano, o Congresso impôs variados requisitos à indústria e aos governos federal, estaduais e locais. Dentre as providências que foram tomadas, é de ressaltar o Toxics Release Inventory (TRI), que impõe a divulgação obrigatória da quantidade de produtos químicos potencialmente perigosos armazenados ou liberados no meio ambiente, sendo tal informação imediatamente disponibilizada no sítio da Environmental Protection Agency (EPA) para quem quiser acessá-la. O que, a princípio, tinha o condão de informar a EPA, acabou por figurar, ressaltam Thaller e Sustein, um dos casos de maior sucesso no direito ambiental - e, é mister que se diga, um nudge social, afinal, a liberação de produtos tóxicos nos Estados Unidos foi reduzida em grande escala, sem que tenha havido sequer a obrigação de uma mudança de comportamento. Assinalam os autores que a má publicidade acarretada pela inserção das empresas na intitulada enviromental blacklist — a saber, uma lista elaborada por grupos ambientalistas e pela mídia em geral que nominava os piores transgressores — foi o principal motivo para tamanho êxito. Ninguém queria ser listado e o resultado que se obteve foi uma espécie de competição travada entre as companhias, que faziam o possível para não aparecerem na lista negra. ${ }^{2}$

Isto posto, indaga-se: o que é nudge, na perspectiva de Thaller e Sustein?

A nudge, as we will use them, is any aspect of the choice architecture that alters people's behavior in a predictable way without forbidding any options or significantly changing their economic incentives. To count as a mere nudge, the intervention must be easy and cheap to avoid. Nudges are not mandates. Putting the fruit at eye level counts as a nudge. Banning junk food does not. ${ }^{3}$

A ideia central de nudge — a determinar, aliás, que não se faça uso de proibições nem de obrigações — é o paternalismo libertário. Nele, a escolha, apesar de guiada, deve ter a sua liberdade preservada. Paternalismo, como utilizado por Thaller e Sustein, diz respeito à legitimidade que o Poder Público e as instituições privadas têm para influenciar as pessoas nas suas escolhas e, a partir daí, guiá-las para uma vida mais longa, saudável e melhor. Os autores vão além e argumentam que as pessoas necessitam desse direcionamento porquanto, em sua maioria, são homo sapiens e não homo economicus e que, ipso facto, não tomam as melhores decisões em todo o tempo - ou, pelo menos, as melhores decisões que tomariam se quiçá fossem as circunstâncias diferentes. Elucidam Thaller e Sustein:

The paternalistic aspect lies in the claim that it is legitimate for choice architects to try to influence people's behavior in order to make their lives longer, healthier, and better. In other words, we argue for self-conscious efforts, by institutions in the private sector and also by government, to steer people choice's in directions that will improve their lives. In our understanding, a policy is "paternalistic" if it tries to influence choices in a way that will make choosers better off, as judged by themselves. Drawing on some well-estabilished findings in social sciences, we show that in many cases, individuals make pretty bad decisions — decisions they would not have made if they had paid full attention and possessed complete information, unlimited cognitive abilities, and complete self-control. ${ }^{4}$

Assim, se veicular na internet um ranking classificatório das empresas que liberam no meio ambiente produtos químicos potencialmente perigosos pode acarretar o investimento delas em segurança no manuseio desses produtos, por que não o fazer? Não é demais notar, aos que resistem aos nudges por se fiarem em uma liberdade de escolha irrestrita, que não se está a proibir o armazenamento ou a liberação de produtos tóxicos. As empresas não estão sendo obrigadas a qualquer tipo de comportamento. O paternalismo é libertário, preservando, por assim dizer, a liberdade. O paternalismo libertário constitui, por conseguinte, "a relatively weak, soft, and nonintrusive type of paternalism because choices are not blocked, fenced off, or significantly burdened." 5

2 THALER, Richard H.; SUSTEIN, Cass R. Nudge: improving decisions about health, wealth, and happiness. New York: Penguin Books, 2009. p. 192-193.

3 THALER, Richard H.; SUSTEIN, Cass R. Nudge: improving decisions about health, wealth, and happiness. New York: Penguin Books, 2009. p. 6.

4 THALER, Richard H.; SUSTEIN, Cass R. Nudge: improving decisions about health, wealth, and happiness. New York: Penguin Books, 2009. p. 5.

5 THALER, Richard H.; SUSTEIN, Cass R. Nudge: improving decisions about health, wealth, and happiness. New York: Penguin Books, 2009. p. 5. 
Um último aspecto que se considera oportuno para a identificação de nudges diz respeito aos incentivos financeiros. Ao delinear nudges - até para diferenciá-los de situações em que a mudança de comportamento foi ocasionada exclusivamente pelos incentivos pecuniários —-, desconsideraram os autores os cenários em que foram oferecidos substanciais incentivos financeiros.

Uma política pública baseada em nudges, consequentemente, deve visar à alteração de um comportamento sem, no entretanto, se servir nem de proibições nem sequer de obrigações nem mesmo do oferecimento de avultosos incentivos econômicos. É o que se deve ter em mente para a compreensão do que será exposto a seguir.

Dito isto, pergunta-se: o Poder Público pode, via nudges, encorajar as empresas que projetem contratos com a Administração Pública a implementarem programas de integridade? Certamente, sim. Um programa de integridade compreende métodos de análise e gestão de riscos e auditoria, em contínuo monitoramento, voltados não somente para uma gestão de eficiência, como para o cumprimento das normas postas pelos Poderes, órgãos regulamentadores e a própria empresa. Tudo isso integrado no mapa de comunicação da empresa, sendo objeto de cursos e treinamentos, aliado à implementação de um canal de denúncias e a ações de responsabilização daqueles que se desviarem do rumo proposto pela companhia, acaba por constituir verdadeiro mecanismo de integridade, gestão eficiente e proteção à reputação da empresa e ao seu próprio corpo de funcionários. Não obstante isso, a implantação de programas de integridade é custosa e, no mais das vezes, envolve alteração de toda uma cultura não somente da empresa, mas do próprio ramo em que atua. Algumas instituições privadas têm optado — nalguns setores, inclusive, por certa imposição de mercado - a adotar programas de compliance $e^{6}$. Mas o Poder Público seguramente pode acelerar esse processo por meio de uma política pública baseada em nudges.

Como seria uma política pública com esse escopo?

Já se lançou a primeira ideia. Um nudge social. A disponibilização na internet — se possível, no portal da transparência — de uma listagem com as instituições públicas e privadas possuidoras de programas de integridade. Poder-se-ia, inclusive, ir além e relacionar aquelas que já tiveram os seus programas avaliados como efetivos pela Administração Pública. É basicamente o que tem sido feito no programa empresa Pró-Ética? Nele, o Ministério da Transparência e Controladoria-Geral da União (CGU), com o objetivo de incitar a adoção de mecanismos e ações de integridade e combate à corrupção no setor privado, avalia os programas de integridade das empresas que, voluntariamente e em tempo, se inscreveram no programa anual. Em 2017, 23 empresas foram aprovadas e reconhecidas como Empresa Pró-Ética. Urge ressaltar a ênfase dada pela própria CGU ao fato de que o programa não serve de certificação nem sequer de salvo conduto para a prática de irregularidades, tendo a participação das empresas nessa iniciativa os benefícios da publicidade positiva, resultado do reconhecimento público de terem sido identificadas como empresas comprometidas com a prevenção e o combate à corrupção, e de avaliação dos seus programas de integridade por equipe especializada.

Além disso, a mera divulgação da implementação de programas de integridade por empresas que possuem contratos com a Administração Pública já atuaria, consoante Thaller e Sustein, como nudge, servindo como influência social: "Social influences come in two basic categories. The first involves information. If many people do something or think something, their actions and their thoughts convey information about

6 Faz-se mister registrar que programas de compliance e programas de integridade não são sinônimos. A grosso modo, compliance significa estar em conformidade com as leis e regulamentos, internos e externos, ao passo que integridade "significa mais do que simplesmente observar as normas, os códigos e as leis decorrentes dos valores e princípios. As normas e leis proporcionam um limite mínimo, um ponto de partida para a moralidade." BRASIL. Tribunal de Contas da União. Referencial de combate à fraude e corrup̣cão: aplicável a órgãos e entidades da Administração Pública. 2017. Disponível em: <http://portal.tcu.gov.br/biblioteca-digital/ referencial-de-combate-a-fraude-e-corrupcao.htm>. Acesso em: 28 maio 2018). Nessa senda, é que Fonseca sugere que "programa de integridade implica um grau de efetividade mais profundo do que programa de compliance."

7 Para maiores informações, acesse o sítio http://www.cgu.gov.br/assuntos/etica-e integridade/empresa-pro-etica/saiba-mais 
what might be best for you to do or think."”

Nessa perspectiva, acresce notar o experimento realizado por agentes de tributação em Minnesota, descrito pelos autores. Nele, os contribuintes foram divididos em grupos, sendo dadas informações distintas a cada um. Ao primeiro deles, foi dito que o valor despendido pelos seus contribuintes a título de tributos seria gasto em educação, saúde, proteção contra incêndios e várias outras ações. Os contribuintes de outro grupo foram alertados dos riscos e consequências do não pagamento de tributos. Já o terceiro grupo foi orientado a quem se dirigir caso houvesse confusão no preenchimento dos formulários. E o último grupo foi informado que mais de $90 \%$ dos contribuintes de Minnesota já tinham cumprido a totalidade das suas obrigações tributárias. Apenas a última intervenção, salientam Thaller e Sustein, apresentou resultados significativos. Dizem, com extrema propriedade:

Apparently some taxpayers are more likely to violate the law because of a misperception $[\ldots]$ that the level of compliance is pretty low. When informed that the actual compliance level is high, the become less likely to cheat. It follows that either desirable or undesirable behavior can be increased, at least to some extent, by drawing public attention to what others are doing. ${ }^{9}$

Entrementes e como se está a tratar de uma política pública que venha a incitar as empresas que projetem contratos com a Administração Pública a implementar programas de integridade, cabe repisar que, também, a publicidade negativa, resultado da condenação de uma empresa em atos de improbidade administrativa, tem a sua relevância. Nesse contexto, vale registrar o Cadastro Nacional de Empresas Punidas (CNEP), um banco de informações geridas pela CGU que relaciona as empresas que sofreram punições previstas na Lei n ${ }^{\circ}$ 12.846/2013 no âmbito dos Poderes Executivo, Legislativo e Judiciário de todos os entes da federação.

Outra ideia seria tornar acessível e de fácil compreensão não somente os custos associados à corrupção ${ }^{10}$ como a sua repercussão em nível de políticas públicas. Afinal, quanto custa a corrupção para um País? Rose-Ackerman aborda o assunto sob um viés econômico, destacando três tripés: investimento estrangeiro, mercado e respeito à legislação. Com propriedade e rigor, acentua que a corrupção elevada desencoraja o investimento estrangeiro, introduz custos e distorções no mercado e incita o desrespeito ao ordenamento jurídico, especialmente às legislações tributária e a reguladora. ${ }^{11}$ São indubitáveis os efeitos deletérios da corrupção no crescimento do País. Sem embargo, sugere-se que uma política pública baseada em nudges verse sobre os custos da corrupção de modo mais prático, preciso. A percepção da corrupção no setor público no Brasil é extrema. Nessa perspectiva, vale registrar o Corruption Perceptions Index (CPI), criado pela Transparency International ${ }^{2}$ a partir da expertise de analistas e empresários. No ano de 2018, o Brasil foi pontuado, numa escala de 0 a 100, em que 0 significa altamente corrupto e 100 significa um País muito íntegro, com 37 pontos e foi classificado na $96^{a}$ posição, dentre os 180 Países analisados. Tal percepção, em níveis elevados, é conveniente desde que resulte em esforços para o seu enfrentamento. Para evitar que a alta percepção da corrupção no setor público conduza a um sentimento de conformismo, de desesperança, mister se faz salientar os custos da corrupção de forma mais concreta, evidenciando a sua repercussão nas políticas públicas a que se poderia ter levado a cabo se acaso o dinheiro não tivesse sido desviado. Em 2010, a Federação das

8 THALER, Richard H.; SUSTEIN, Cass R. Nudge: improving decisions about health, wealth, and happiness. New York: Penguin Books, 2009. p. 54.

9 THALER, Richard H.; SUSTEIN, Cass R. Nudge: improving decisions about health, wealth, and happiness. New York: Penguin Books, 2009. p. 67.

10 Este artigo não se presta a examinar minuciosamente a corrupção. No entretanto, é relevante ter em mente que, nada obstante o termo corrupção vir sendo largamente utilizado, adotou-se, até por se estar a tratar de custos, a concepção de Rose-Ackerman que praticamente igualou a corrupção ao suborno, identificando-a no momento em que uma terceira pessoa, susceptível de ser favorecida por ato de um funcionário público e buscando influenciar a sua decisão, a ele ilegalmente paga quantia em dinheiro. ROSE-ACKERMAN, Susan. Corruption: a study in political economy. New York: Academic Press, Inc., 1978. p. 6.

11 ROSE-ACKERMAN, Susan. Corruption and government: causes, consequences, and reform. Cambridge: Cambridge University Press, 1999. p. 3.

12 A Transparência Internacional é uma ONG que, desde 1996, anualmente pontua e classifica países e territórios com base na percepção da corrupção no setor público. O seu Índice de Percepção da Corrupção (IPC) é o indicador de corrupção mais utilizado no mundo. 
Indústrias do Estado de São Paulo (FIESP) estimou, com base em dados colhidos entre 1990 a 2008, que o Brasil perde por ano com atos de corrupção em média $\mathrm{R} \$ 41,5$ bilhões a $\mathrm{R} \$ 69,1$ bilhões, o que representava à época $1,38 \%$ a $2,3 \%$ do produto interno bruto brasileiro. ${ }^{13}$ Isto equivalia, no seu percentual mínimo, a $27 \%$ dos gastos efetuados com educação ou, ainda, a 40\% do que se gastou no ano com saúde em todo o Brasil — arrematou a federação no relatório "Corrupção: custos econômicos e propostas de combate". ${ }^{14} \mathrm{O}$ relatório da FIESP poderia ter ido além e aclarado, ainda mais, a repercussão da corrupção nas políticas públicas daquele ano. Bastava ter precisado quantas escolas públicas poderiam ter sido construídas ou reformadas com $\mathrm{R} \$ 41,5$ bilhões ou quantos hospitais poderiam ter sido construídos, reformados e/ou aparelhados ou, ainda, quantos profissionais de educação e de saúde poderiam ter sido contratados com o respectivo valor. O relatório em comento foi publicado na internet em 35 páginas e noticiado em jornais em todo o Brasil, podendo, ainda hoje, ser acessado na íntegra. Assim como ele, inúmeros estudos sobre a corrupção, com definições, causas e custos, foram disponibilizados na internet para o acesso de quem sobre eles tiver interesse. O ritmo acelerado cotidiano, no entretanto, nem sempre permite que as pessoas se inteirem de tudo o que as interessam e, sem informação, acabam não tendo reação. Daí o préstimo de se compilar e se transformar valores e percentuais em perdas concretas em políticas públicas.

O que se propõe guarda similitude com o raciocínio adotado por Thaller e Sustein quando descrevem o caso da EPA e dos adesivos de economia de combustível. Explica-se. Nos Estados Unidos, como medida para se atingir os padrões de economia de combustível esperados dos novos veículos, estimulando uma competição entre as empresas em relação à fabricação de automóveis que consomam menos, os carros novos devem conter adesivo a indicar a economia de combustível que se pode esperar de cada modelo. Neles, Thaller e Sustein identificam poderoso nudge, desde que, além da indicação de milhas por galão, contenham estimativas anual e quinquenal do valor a ser gasto com combustível:

But what, exactly, do mileage numbers mean? For most of us, the answer isn't at all obvious. The goal of promoting competition could be accomplished far more effectively by translating the mileage into dollars, solving the mapping problem. [...] We applaud the new stickers, though we think they might be even more powerful if they computed a five-year figure for money spent on fuel. Imagine the sticker on a Hummer! Even better would be to post these numbers on the back of the car for other drivers to see. ${ }^{15}$

Não é demais observar que informar as milhas por galão mostra-se, na teoria, suficiente para incitar a compra por um carro que consoma menos. Ainda assim e com o objetivo de melhor atingir o objetivo proposto - a saber: proteger o meio ambiente ao reduzir o consumo de combustível —, os autores sugerem uma abordagem mais franca e com maior impacto, enfatizando o custo financeiro. A ideia central, repise-se, é símile à da repercussão dos custos da corrupção nas políticas públicas. Acredita-se que uma melhor conscientização da população tornará propício um ambiente em que empresas que tenham programas de integridade, especialmente aquelas que projetem contratos com a Administração Pública, sejam valorizadas.

No que concerne especificamente ao regime de licitações e contratações pelo poder público, pode-se sugerir, ainda, que a existência de programa de integridade figure como critério de pontuação nas licitações e contratações realizadas pela Administração Pública sob os tipos de melhor técnica e técnica e preço, tudo em consonância com o art. 46, $\$^{\circ}$, I da Lei no 8.666/93. É o que sugerem, com extrema propriedade, Guimarães e Requi:

13 FEDERAÇÃO DAS INDÚSTRIAS DO ESTADO DE SÃO PAULO (FIESP). Corrupção: custos econômicos e propostas de combate. 2010. p. 26. Disponível em: <https: $/$ www.google.com.br $/$ url? $\mathrm{sa}=\mathrm{t} \& \mathrm{rct}=\mathrm{j} \& \mathrm{q}=\&$ esrc $=\mathrm{s} \& \mathrm{source}=\mathrm{web} \& \mathrm{~cd}=1 \& \mathrm{ved}=0 \mathrm{ah}$ UKEwiTiPXCxaTbAhWMfZAKHZJNCj0QFggnMAA\&url=http $\% 3 \mathrm{~A} \% 2 \mathrm{~F} \% 2 \mathrm{Fwww}$.fiesp.com.br $\% 2 \mathrm{Farquivo}$-download $\% 2 \mathrm{~F} \%$ 3Fid\%3D2021\&usg=AOvVaw3nuNdZSkRM1WlFoJrzc3Up>. Acesso em: 26 maio 2018.

14 FEDERAÇÃO DAS INDÚSTRIAS DO ESTADO DE SÃO PAULO (FIESP). Corrup̧cão: custos econômicos e propostas de combate. 2010. p. 28. Disponível em: $<$ https: $/ /$ www.google.com.br $/$ url? $\mathrm{sa}=\mathrm{t} \& \mathrm{rct}=\mathrm{j} \& \mathrm{q}=\& \mathrm{esrc}=\mathrm{s} \& \mathrm{source}=\mathrm{web} \& \mathrm{~cd}=1 \& \mathrm{ved}=0 \mathrm{ah}$ UKEwiTiPXCxaTbAhWMfZAKHZJNCj0QFggnMAA\&url=http $\% 3 \mathrm{~A} \% 2 \mathrm{~F} \% 2 \mathrm{Fwww}$.fiesp.com.br $\% 2 \mathrm{Farquivo}$-download $\% 2 \mathrm{~F} \%$ 3Fid\%3D2021\&usg=AOvVaw3nuNdZSkRM1WlFoJrzc3Up>. Acesso em: 26 maio 2018.

15 THALER, Richard H.; SUSTEIN, Cass R. Nudge: improving decisions about health, wealth, and happiness. New York: Penguin Books, 2009. p. 193-194. 
Nada impede, contudo, que a comprovação da existência de um programa de integridade possa figurar como critério de pontuação de propostas técnicas, em licitações que funcionam sob critérios de técnica e preço ou melhor técnica. Será perfeitamente admissível que exigências assim possam constar dos editais de licitação, com fundamentos no inc. I do $₫ 1^{\circ}$ do art. 46 da Lei no 8.666/93. ${ }^{16}$

Assim, em querendo uma melhor pontuação no procedimento licitatório, a empresa poderia declarar a existência do programa, que, então, seria avaliado pela comissão de licitação. Se, por sua vez, quiser participar da licitação empresa que não tiver programa de integridade, a ela será permitida não somente a participação como a contratação na hipótese de ter sido consagrada vencedora do certame.

Por derradeiro, é importante que a própria Administração Pública desvele o seu comprometimento com o enfrentamento da corrupção, indicando os programas de integridade como uma vereda a ser seguida. Para tanto, a primeira recomendação seria a regulamentação pelos demais entes federados da Lei n $12.846 / 2013$. Até meados de 2018, apenas 16 Estados brasileiros haviam regulamentado a referida lei. ${ }^{17}$ Não é este o local adequado para analisar os motivos e a repercussão dessa não regulamentação. É suficiente, nesse momento, que se esclareça que, apesar de a ausência de regulamentação não impedir a responsabilização civil e administrativa das empresas por atos praticados contra o poder público estadual, dificulta-a, uma vez que não foram atribuídas, no âmbito do ente federado, as competências para fiscalizar e investigar os atos contra a administração pública, aplicar sanções, firmar acordos de leniência, dentre outras.

Ademais, os próprios Estados, a exceção do Estado de Mato Grosso, não têm programas de integridade implementados. O teor da mensagem que o Estado passaria ao empresário no momento em que dele requeresse um programa de integridade seria diferente se ele, ente federado, também o tivesse.

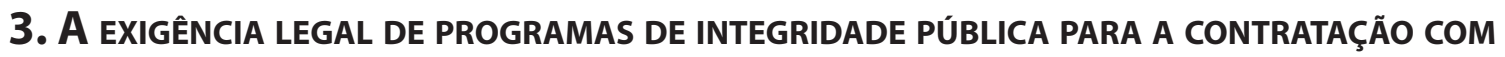 a Administração Pública estadual: Um olhar sobre a sua constitucionalidade e OPORTUNIDADE}

Em outubro de 2017, no Estado do Rio de Janeiro, veio a lume a Lei n ${ }^{\circ} 7.753$, marco legislativo estadual para a exigência de implantação de programas de integridade nas empresas que celebrarem contratos com a Administração Pública carioca nos valores e períodos estipulados.

Com efeito, somente poderão firmar contratos, consórcios, convênios, concessões ou parcerias público-privadas cujos valores sejam superiores aos de licitação na modalidade concorrência e com prazo superior a 680 dias com a administração pública direta, indireta e fundacional do Estado do Rio de Janeiro, empresas com programas de integridade implantados ou em fase de implantação — sujeita esta ao prazo de 180 dias corridos $\left(\operatorname{art} .5^{\circ}\right)$.

O aprofundamento da Lei Estadual n $n^{\circ} 7.753 / 2017$ não seria pertinente neste artigo. É relevante ter em mente, apenas, que a legislação desce a minúcias, trazendo conceitos (art. $3^{\circ}$ ), parâmetros de avaliação (art. $4^{\circ}$ ) e sanções no caso de descumprimento $\left(\operatorname{art.} 6^{\circ}\right)$.

O Distrito Federal, também, aprovou legislação que passou a obrigar a implementação dos programas

16 GUIMARÃES, Fernando Vernalha; REQUI, Érica Miranda dos. Exigência de programa de integridade nas licitações. In: PAULA, Marco Aurélio Borges de; CASTRO, Rodrigo Pironti Aguirre de (Org.). Compliance, gestão de riscos e combate à corrupção: integridade para o desenvolvimento. Belo Horizonte: Fórum, 2018. p. 214.

17 São eles: Tocantins (Decreto no 4.954/13), São Paulo (Decreto no 60.106/14), Paraná (Decreto no 10.271/14), Goiás (Lei no 18.672/14), Rio Grande do Norte (Decreto no 25.177/15), Minas Gerais (Decreto no 46.782/15), Maranhão (Decreto no 31.251/15), Mato Grosso (Decreto no 522/16), Distrito Federal (Decreto no 37.296/16), Espírito Santo (Decreto no 3.956-R/16, com redação alterada pelo Decreto $n^{\circ}$ 3.971-R/16), Santa Catarina (Decreto no 1.106/17), Mato Grosso do Sul (Decreto $n^{\circ}$ 14.890/17), Alagoas (Decreto $n^{\circ}$ 52.555/17), Rio de Janeiro (Decreto $n^{\circ}$ 46.366/2018), Pernambuco (Lei $n^{\circ} 16.309 / 2018$ ) e Paraíba (Decreto $n^{\circ}$ $38.308 / 2018)$. 
em comento por empresas que projetem contratos com a Administração Pública estadual. Apesar de a Lei distrital no 6.112/2018 ter sido estruturada de modo símile à lei carioca, veio obrigar já os contratos cujos valores sejam superiores aos de licitação na modalidade tomada de preços e com prazo superior a 180 dias.

Levando em consideração o art. 22, XXVII da Constituição, que atribui privativamente à União legislar sobre normas gerais de licitação e contratação para as administrações públicas diretas, autárquicas e fundacionais de todos os entes federados, o que dizer da constitucionalidade de dispositivo de lei estadual que impõe obrigações à contratação pública? A doutrina, até o presente momento, não tem se debruçado sobre a questão. Convém proceder à análise de um e outro argumento.

Para os que consideram inconstitucional o dever, por imposição de lei estadual, de as empresas que contratarem com a Administração Pública implementarem programas de integridade, estaria o legislador estadual, ao fazê-lo, malferindo o art. 22, XXVII da Constituição. Isso porque sujeitar a contratação com o poder público, de maneira tão ampla, configuraria norma geral e uma que iria de encontro aos princípios da competitividade e da igualdade de condições entre os participantes de uma licitação pública. Ao analisar as leis do Rio de Janeiro e do Distrito Federal, Pinho alerta para a questão do caráter geral de norma que condiciona a contratação com o poder público e, portanto, da necessidade de que seja veiculada por lei nacional, conforme cita-se: "Inegavelmente, lei estadual criou uma condição especial para a assinatura de contrato administrativo, o que, em nosso modo de ver, acaba por criar restrição que somente poderia se veicular por meio de norma geral, de competência privativa da União."18

O Supremo Tribunal Federal (STF) ainda não teve a oportunidade de se pronunciar sobre o assunto. Contudo, a Corte Constitucional, na ADI n ${ }^{\circ} 3.735 / \mathrm{MS}$, já se manifestou pela inconstitucionalidade da Lei $n^{\circ}$ 3.041/2005, do Estado de Mato Grosso do Sul, que instituía a intitulada Certidão de Violação aos Direitos do Consumidor (CVDC), documento este a ser exigido na contratação com a administração pública estadual e suas autarquias, empresas públicas e sociedades de economia mista que integrasse.

Não é demais observar a similitude entre as exigências da Lei no 3.041/2005, do Mato Grosso do Sul, e das Leis $n^{\circ} 7.753 / 2017$, do Rio de Janeiro, e 6.112/2018, do Distrito Federal. Em todas elas, leis de âmbito estadual exigem documentação fora do art. 27 da Lei no ${ }^{\circ} 8.666 / 1993^{19}$ para a contratação com o poder público estadual.

À vista disso, convém minuciar os fundamentos adotados no julgamento da ADI no 3.735/MS, referida alhures. A decisão da Corte Excelsa se baseou no tripé: autonomia dos entes federados para legislar sobre licitações e contratos, atendimento da legislação estadual à sua competência suplementar e definição das normas gerais do art. 22, XXVII da CF/88. É o que sucintamente se passa a explicar.

A primeira questão que se coloca é a da autonomia dos entes federados para legislar sobre licitações e contratos. Isso porque se questionou se os Estados poderiam legislar sobre o assunto, uma vez que a Constituição, ex vi do art. 22, parágrafo único, reclama lei complementar a autorizá-los a legislar sobre questões específicas sobre as matérias relacionadas no artigo. A interpretação dada pelo STF foi a de que a própria Constituição, ao prever no art. 22, XXVII que "compete privativamente à União legislar sobre normas gerais de licitação e contratação", tornou prescindível a autorização formal para as normas ditas "não gerais". Sendo assim, Estados e Municípios, no exercício das competências que lhes são próprias (arts. 24 e 25 , $\ 1^{\circ}$

18 PINHO, Clóvis Alberto Bertolini de. É preciso cautela ao exigir compliance em contrato público. Revista Consultor Jurídico, 2018. Disponível em: <https://www.conjur.com.br/2018-fev-18/clovis-pinho-preciso-cautela-compliance-contrato-publico>. Acesso em: 28 maio 2018.

19 "Para a habilitação nas licitações exigir-se-á dos interessados, exclusivamente, documentação relativa a: I - habilitação jurídica; II - qualificação técnica; III - qualificação econômico-financeira; IV - regularidade fiscal e trabalhista; V - cumprimento do disposto no inciso XXXIII do art. $7^{\circ}$ da Constituição Federal. " BRASIL. Lei no 8.666, de 21 de junho de 1993. Regulamenta o art. 37, inciso XXI, da Constituição Federal, institui normas para licitações e contratos da Administração Pública e dá outras providências. Diário Oficial da União, Brasília, 22 jun. 1993. Disponível em: < http://www.planalto.gov.br/ccivil_03/Leis/18666cons.htm>. Acesso em: 20 maio 2018. 
e art. 30, II, respectivamente), podem, independentemente de lei complementar autorizativa, legislar sobre licitação e contratação. Saliente-se, porém, não ser essa autonomia de todo incondicionada. Devem os Estados e os Municípios fazer dela uso como se de natureza suplementar fosse. Eis a segunda questão. No particular, merece registro o teor do voto do Ministro Ayres Britto proferido na ADI nº 3.059/RS, que declarou a constitucionalidade de dispositivo de lei estadual que instituía a preferência pela aquisição de softwares livres nas licitações da Administração Pública regional:

É de se questionar, então: as normas gerais de licitação e contratação, editadas pela União, têm por contraponto, no âmbito dos Estados e do Distrito Federal, normas específicas ou normas suplementares? Resposta: a competência que assiste aos Estados e ao Distrito Federal, em matéria de licitação, é de natureza suplementar. Embora topograficamente inserida no art. 22 da Constituição Federal, a competência da União para legislar sobre licitação e contratação, em todas as modalidades, para as Administrações Públicas Diretas, autárquicas e fundacionais da União, Estados, Distrito Federal e Municípios se limita à edição de normas gerais (inciso XXVII do art. 22 da CF), assim como a competência legislativa de todas as matérias referidas no art. 24 da Constituição ( $\$ 1^{\circ}$ do art. 24 da CF). Ademais, inexistindo lei federal sobre normas gerais de licitação, ficam os Estados autorizados a exercer a competência legislativa plena para atender a suas peculiaridades $\left(\$ 3^{\circ}\right.$ do art. 24 da $\left.\mathrm{CF}\right)$. A não ser assim, o que se tem é recusa aos Estados membros quanto a sua própria autonomia administrativa, quebrantando o princípio federativo. ${ }^{20}$

Nessa perspectiva, cabia indagar se a lei sul-mato-grossense, ao exigir aos que contratassem com o poder público estadual uma CVDV, ateve-se aos limites de sua competência suplementar, legislando com base nas normas gerais de contratação veiculadas na Lei no 8.666/1993, ou se, a pretexto de assim proceder, substituiu-se ao legislador nacional, editando normas gerais sobre o assunto que se contrapõem ao regime geral de licitações e contratações. Pela última opção se pronunciou o STF. Desponta a terceira questão: a da definição das normas gerais. Necessário se faz identificar as normas gerais sobre licitação e contratação administrativa para, empós, avaliar o caso concreto e aferir se há contraste entre as disposições de ordem nacional e estadual.

Isto posto, indaga-se: o que são normas gerais em matéria de licitação e contratação com o setor público? Sobre o assunto, não há consenso. Justen Filho preleciona lição de incontestável peso:

Assim, pode-se afirmar que norma geral sobre licitação e contratação administrativa é um conceito jurídico indeterminado cujo núcleo de certeza positiva compreende a disciplina imposta pela União e de observância obrigatória por todos os entes federados (inclusive da Administração indireta), atinente à disciplina de: (a) requisitos mínimos necessários e indispensáveis à validade da contratação administrativa; (b) hipóteses de obrigatoriedade e de não obrigatoriedade de licitação; (c) requisitos de participação em licitação; (d) modalidades de licitação; (e) tipos de licitação; (f) regime jurídico de contratação administrativa. ${ }^{21}$

20 Brasil. Supremo Tribunal Federal. Ação Direta de Inconstitucionalidade. Constitucional e administrativo. Lei 3.041/05, do Estado do Mato Grosso do Sul. Licitações e contratações com o poder público. Documentos exigidos para habilitação. Certidão negativa de violação a direitos do consumidor. Disposição com sentido amplo, não vinculada a qualquer especificidade. Inconstitucionalidade formal, por invasão de competência privativa da União para legislar sobre a matéria (Art. 22, inciso XXVII, da CF). 1. A igualdade de condições dos concorrentes em licitações, embora seja enaltecida pela Constituição (art. 37, XXI), pode ser relativizada por duas vias: (a) pela lei, mediante o estabelecimento de condições de diferenciação exigíveis em abstrato; e (b) pela autoridade responsável pela condução do processo licitatório, que poderá estabelecer elementos de distinção circunstanciais, de qualificação técnica e econômica, sempre vinculados à garantia de cumprimento de obrigações específicas. 2. Somente a lei federal poderá, em âmbito geral, estabelecer desequiparações entre os concorrentes e assim restringir o direito de participar de licitações em condições de igualdade. Ao direito estadual (ou municipal) somente será legítimo inovar nesse particular se tiver como objetivo estabelecer condições específicas, nomeadamente quando relacionadas a uma classe de objetos a serem contratados ou a peculiares circunstâncias de interesse local. 3. Ao inserir a Certidão de Violação aos Direitos do Consumidor no rol de documentos exigidos para a habilitação, o legislador estadual se arvorou na condição de intérprete primeiro do direito constitucional de acesso a licitações e criou uma presunção legal, de sentido e alcance amplíssimos, segundo a qual a existência de registros desabonadores nos cadastros públicos de proteção do consumidor é motivo suficiente para justificar o impedimento de contratar com a Administração local. 4. Ao dispor nesse sentido, a Lei Estadual 3.041/05 se dissociou dos termos gerais do ordenamento nacional de licitações e contratos, e, com isso, usurpou a competência privativa da União de dispor sobre normas gerais na matéria (art. 22, XXVII, da CF). 5. Ação direta de inconstitucionalidade julgada procedente. Procurador Geral da República. Governador do Estado do Mato Grosso do Sul e outro. Relator: Ministro Teori Zavascki. Brasília, DF, 08 de set. de 2016. Diário Oficial da União, Brasília, 2016.

21 JUSTEN FILHO, Marçal. Comentários à lei de licitações e contratos administrativos. 15. ed. São Paulo: Dialética, 2012. p. 16. 
Perceba-se, portanto, que as normas que disponham sobre os requisitos mínimos de contratação e de participação em licitação foram elencadas pelo autor como normas gerais. Esta foi igualmente a opinião exarada pelo relator da ADI n $3.735 / \mathrm{MS}$, o ministro Teori Zavascki, e ratificada pela maioria dos ministros presentes. Daí resulta que o legislador estadual (ou municipal), ao tratar do assunto, deve ter a cautela de, reprise-se, legislar a partir da Lei no 8.666/1993, e não ir de encontro aos seus preceitos. As condicionantes porventura estabelecidas devem, portanto, ater-se a uma classe de objetos contratados (como, e.g., obras de infraestrutura de alta complexidade) ou a peculiaridades do local. Exigir aos que contratassem com o poder público estadual uma CVDV, como intentava a Lei no 3.041/2005, do Estado de Mato Grosso do Sul, era regra por demais ampla para se enquadrar em quaisquer das exceções supracitadas. Nas precisas palavras do relator da $\mathrm{ADI} \mathrm{n}^{\circ} 3.735 / \mathrm{MS}$ :

Ao criar este requisito de habilitação, obrigatório para a grande maioria dos contratos estaduais, o Estado de Mato Grosso do Sul se arvorou na condição de intérprete primeiro do direito constitucional de participar de licitações e criou uma presunção legal, de sentido e alcance amplíssimos, segundo a qual a existência de registros desabonadores nos cadastros públicos de proteção do consumidor é motivo suficiente para justificar o impedimento à contratação de pessoas físicas e jurídicas pela Administração local. Embora a CVDC se aplique apenas aos contratos de valores superiores a cinquenta UFERMS (unidade fiscal estadual de referência de Mato Grosso do Sul), a sua exigência está longe de configurar uma condição especificamente ligada a determinado tipo de objeto. Muito pelo contrário, trata-se de uma limitação não episódica, aplicável linearmente à grande maioria dos contratos estaduais. ${ }^{22}$

Com o apoio da melhor doutrina ${ }^{23}$, Dallari corrobora: "Não é norma geral aquela que corresponde a uma especificação, a um detalhamento. Portanto, norma geral é aquela que cuida de determinada matéria de maneira ampla. Norma geral é aquela que comporta uma aplicação uniforme pela União, Estado e Município."24

Dessarte, ao exigir requisito genérico e inteiramente novo, a lei sul-mato-grossense não teria desdobrado os requisitos constantes no rol do art. 27 da Lei n ${ }^{\circ}$ 8.666/93 para a contratação de uma classe de objetos ou a adequação deles a peculiaridades do local. Ao fazê-lo, o legislador estadual acabou por afrontar, conforme entendimento da maioria dos ministros do STF, a competitividade e a igualdade de condições a todos os concorrentes (art. 37, XXI da CF/88), que, além de normas gerais, podem ser consideradas princípios basilares do procedimento licitatório.

22 BRASIL. Supremo Tribunal Federal. Ação Direta de Inconstitucionalidade. Constitucional e administrativo. Lei 3.041/05, do Estado do Mato Grosso do Sul. Licitações e contratações com o poder público. Documentos exigidos para habilitação. Certidão negativa de violação a direitos do consumidor. Disposição com sentido amplo, não vinculada a qualquer especificidade. Inconstitucionalidade formal, por invasão de competência privativa da União para legislar sobre a matéria (Art. 22, inciso XXVII, da $\mathrm{CF}$ ). 1. A igualdade de condições dos concorrentes em licitações, embora seja enaltecida pela Constituição (art. 37, XXI), pode ser relativizada por duas vias: (a) pela lei, mediante o estabelecimento de condições de diferenciação exigíveis em abstrato; e (b) pela autoridade responsável pela condução do processo licitatório, que poderá estabelecer elementos de distinção circunstanciais, de qualificação técnica e econômica, sempre vinculados à garantia de cumprimento de obrigações específicas. 2. Somente a lei federal poderá, em âmbito geral, estabelecer desequiparações entre os concorrentes e assim restringir o direito de participar de licitações em condições de igualdade. Ao direito estadual (ou municipal) somente será legítimo inovar neste particular se tiver como objetivo estabelecer condições específicas, nomeadamente quando relacionadas a uma classe de objetos a serem contratados ou a peculiares circunstâncias de interesse local. 3. Ao inserir a Certidão de Violação aos Direitos do Consumidor no rol de documentos exigidos para a habilitação, o legislador estadual se arvorou na condição de intérprete primeiro do direito constitucional de acesso a licitações e criou uma presunção legal, de sentido e alcance amplíssimos, segundo a qual a existência de registros desabonadores nos cadastros públicos de proteção do consumidor é motivo suficiente para justificar o impedimento de contratar com a Administração local. 4. Ao dispor nesse sentido, a Lei Estadual 3.041/05 se dissociou dos termos gerais do ordenamento nacional de licitações e contratos, e, com isso, usurpou a competência privativa da União de dispor sobre normas gerais na matéria (art. 22, XXVII, da CF). 5. Ação direta de inconstitucionalidade julgada procedente. Procurador Geral da República. Governador do Estado do Mato Grosso do Sul e outro. Relator: Ministro Teori Zavascki. Brasília, DF, 08 de set. de 2016. Diário Oficial da União, Brasília, 2016.

23 É de ressaltar as lições de Mello, para quem normas gerais são "preceitos que podem ser aplicados uniformemente em todo o País, por se adscreverem a aspectos nacionalmente indiferençados, de tal sorte que repercutem com neutralidade, indiferentemente, em quaisquer de suas regiões ou localidades. " MELLO, Celso Antônio Bandeira de. Curso de Direito Administrativo. 11. ed. São Paulo: Malheiros, 1999.p. 376-377

24 DALLARI, Adilson Abreu. Aspectos jurídicos da licitação. 6. ed. Rio de Janeiro: Saraiva, 1999. p. 20-21. 
Não obstante o acórdão examinado não tratar da exigência, por imposição de lei estadual, de as empresas que contratarem com a Administração Pública implementarem programas de integridade, ocupa-se igualmente de requisito obrigatório para a maioria dos contratos estaduais imposto por legislação regional, prenunciando, assim, um factível posicionamento da Corte Constitucional se acaso for instada a se manifestar sobre a temática.

A predição toma corpo quando se atenta para a jurisprudência do STF, aparentemente consolidada neste sentido, a exemplo da ADI no 3.670/DF, que declarou inconstitucional a Lei Distrital $n^{\circ} 3.705 / 2005$, que proibia a contratação com o poder público de empresas que discriminassem na contratação de mão-de-obra pessoas com os nomes incluídos nos serviços de proteção ao crédito.

Apesar da jurisprudência do STF, não há muitas vozes na doutrina a patrocinarem a inconstitucionalidade da Lei no 7.753/2017, do Rio de Janeiro, ou da Lei no 6.112/2018, do Distrito Federal.

Os que consideram constitucional o dever, por imposição de lei estadual, de as empresas que contratarem com a Administração Pública implementarem programas de integridade o fazem refutando definições muito amplas de normas gerais e argumentando a efetivação pelos referidos programas de um vasto cabedal de princípios valorizados pela Constituição da República, como os da impessoalidade, da moralidade administrativa, da publicidade, da eficiência, da economicidade, dentre outros. É o que se passa a explicar.

A discordância à amplidão do conceito de normas gerais de licitação e contratação encontra suporte no voto dissonante do ministro Marco Aurélio - que, ressalte-se, foi acompanhado pelo ministro Celso de Mello - contido no próprio acórdão da ADI no 3.735/MS, que julgou procedente o pedido formulado para declarar a inconstitucionalidade da Lei no 3.041/2005, do Estado de Mato Grosso do Sul. Diante disso, convém regressar ao acórdão em comento.

Segundo os ministros, correta a definição de normas gerais de Justen Filho trazida aos autos pelo relator. Para o autor - repise-se, normas gerais de licitação e contratação seriam aquelas atinentes a:

(a) requisitos mínimos necessários e indispensáveis à validade da contratação administrativa; (b) hipóteses de obrigatoriedade e de não obrigatoriedade de licitação; (c) requisitos de participação em licitação; (d) modalidades de licitação; (e) tipos de licitação; (f) regime jurídico de contratação administrativa. ${ }^{25}$

O ministro Marco Aurélio, então, enfatiza a expressão “mínimos”, não se esgotando na legislação de competência privativa da União, na sua linha de raciocínio, todos os requisitos de contratação. Fundamentando-se, ademais, na extensa proteção ao consumidor que foi dada pelo ordenamento jurídico brasileiro, encerra: "a meu ver, o Estado atuou, atuou em campo alusivo à defesa do consumidor e atuou sem inobservar as normas gerais, editadas pela União, visando a protegê-lo; atuou a partir de razoabilidade, na espécie, proporcionalidade."26

25 JUSTEN FILHO, Marçal. Comentários à lei de licitaçoes e contratos administrativos. 15. ed. São Paulo: Dialética, 2012. p. 16.

26 BRASIL. Supremo Tribunal Federal. Ação Direta de Inconstitucionalidade. Constitucional e administrativo. Lei 3.041/05, do Estado do Mato Grosso do Sul. Licitações e contratações com o poder público. Documentos exigidos para habilitação. Certidão negativa de violação a direitos do consumidor. Disposição com sentido amplo, não vinculada a qualquer especificidade. Inconstitucionalidade formal, por invasão de competência privativa da União para legislar sobre a matéria (Art. 22, inciso XXVII, da CF). 1. A igualdade de condições dos concorrentes em licitações, embora seja enaltecida pela Constituição (art. 37, XXI), pode ser relativizada por duas vias: (a) pela lei, mediante o estabelecimento de condições de diferenciação exigíveis em abstrato; e (b) pela autoridade responsável pela condução do processo licitatório, que poderá estabelecer elementos de distinção circunstanciais, de qualificação técnica e econômica, sempre vinculados à garantia de cumprimento de obrigações específicas. 2. Somente a lei federal poderá, em âmbito geral, estabelecer desequiparações entre os concorrentes e assim restringir o direito de participar de licitações em condições de igualdade. Ao direito estadual (ou municipal) somente será legítimo inovar nesse particular se tiver como objetivo estabelecer condições específicas, nomeadamente quando relacionadas a uma classe de objetos a serem contratados ou a peculiares circunstâncias de interesse local. 3. Ao inserir a Certidão de Violação aos Direitos do Consumidor no rol de documentos exigidos para a habilitação, o legislador estadual se arvorou na condição de intérprete primeiro do direito constitucional de acesso a licitações e criou uma presunção legal, de sentido e alcance amplíssimos, segundo a qual a existência de registros desabonadores nos cadastros públicos de proteção do consumidor é motivo suficiente para justificar o impedimento de contratar com a Administração local. 4. Ao dispor nesse sentido, a Lei Estadual 3.041/05 se dissociou dos termos gerais do ordenamento nacional de licitações e contratos, 
Não é demais observar ter o voto dissonante silenciado acerca da previsão do art. 27 da Lei nº 8.666/1993 (que arrola a documentação a ser exigida dos licitantes para a habilitação, já analisado) e da questão das normas que, por terem sentido e alcance amplo, podem, em tese, ser aplicadas indistintamente a todos os entes da federação.

O cabedal principiológico da Constituição é decididamente outro dos fundamentos da constitucionalidade de lei estadual exigir programas de integridade para a contratação com o poder público. Isso porque tais programas abrangem uma série de mecanismos de conformidade e de integridade, a serem continuamente disseminados na empresa/entidade pública e auditados, bem como a aplicação de códigos de ética e de conduta, políticas e diretrizes sobre os mais diversos assuntos, objetivando prevenir irregularidades, fraudes e atos de corrupção praticados contra a Administração Pública. Nesse contexto, não apenas princípios diretamente relacionados à ética e à integridade no relacionamento com o poder público são concretizados, como os da moralidade administrativa, da impessoalidade e da publicidade, como outros mais, a exemplo dos que possibilizam uma melhor gestão administrativa e econômica na Administração Pública — princípios da eficácia e da eficiência, respectivamente.

Uma relação com os princípios da moralidade administrativa e da impessoalidade, ambos insculpidos no caput do art. 37 da Constituição, não é difícil de se vislumbrar, derivando basicamente da aplicação dos códigos de conduta e ética e de políticas de relacionamento entre os setores privado e público, um e outro contidos nos programas de integridade.

Também a publicidade, que se densifica nos programas de integridade pública pela recognição que se dá à transparência, é facilmente percebida. Nessa linha de entendimento, Zaganelli e Miranda dilucidam:

[...] embora não seja a única alternativa e seja preciso ainda maiores empenhos, o compliance público contribui, positivamente, para a efetividade das medidas de acesso às informações para o exercício do controle social no combate à malversação dos recursos públicos, tendo em vista os pilares da transparência, integridade e accountability, sendo esse último salutar na esfera pública. ${ }^{27}$

Já o princípio da eficácia se corporifica ante as ferramentas de controle interno e auditorias a serem obrigatoriamente realizadas no âmbito de empresa possuidora de programa de integridade.

Atinente à eficiência, vale registrar a lição de Souza, ao asseverar que "o programa de integridade efetivo, por certo, viabilizará licitações e parcerias administrativas mais eficientes para o Estado, posto que desrevestidas da mácula da corrupção, incrementando os resultados administrativos decorrentes dos negócios jurídicos firmados." 28

Por fim, e sem que haja a pretensão de se esgotar a relação de princípios da administração pública a embasarem os programas de integridade pública, cabe ressaltar os dizeres de Nascimento:

[...] o compliance público aponta para a concretização de uma estratégia inovadora para a esfera pública brasileira, tendo como fundamento os princípios da Administração Pública, previstos no art. 37 da Constituição da. República (legalidade, impessoalidade, moralidade, publicidade e eficiência), entre outros, como a ética, a transparência, a integridade, a justiça, a equidade e a responsabilidade. ${ }^{29}$

Perpassado o ponto da constitucionalidade, resta, ainda, a questão de saber se convém a obrigatoriedade,

e, com isso, usurpou a competência privativa da União de dispor sobre normas gerais na matéria (art. 22, XXVII, da CF). 5. Ação direta de inconstitucionalidade julgada procedente. Procurador Geral da República. Governador do Estado do Mato Grosso do Sul e outro. Relator: Ministro Teori Zavascki. Brasília, DF, 08 de set. de 2016. Diário Oficial da União, Brasília, 2016.

27 ZAGANELLI, Juliana Costa; MIRANDA, Wallace Vieira de. Marco civil da internet e política pública de transparência: uma análise da e-democracia e do compliance público. Revista Brasileira de Políticas Públicas, Brasília, v. 7, n. 3, p. 633-646, 2017.

28 SOUZA, Horácio Mendes Augusto de. A juridicidade da exigência de programa de integridade para participar de licitações e firmar contratos e outras parcerias com o Estado. Revista da Procuradoria-Geral do Estado do Espirito Santo, Vitória, v. 15, n. 15, p. 143169, 2017.

29 NASCIMENTO, Juliana Oliveira. Panorama internacional e brasileiro da governança, riscos, controles internos e compliance no setor público. In: PAULA, Marco Aurélio Borges de; CASTRO, Rodrigo Pironti Aguirre de (Org.). Compliance, gestão de riscos e combate à corrupção: integridade para o desenvolvimento. Belo Horizonte: Fórum, 2018. p. 364. 
por lei estadual, da implementação de programas de integridade para as empresas que contratarem com a Administração Pública regional.

Para Guimarães e Requi, "exigências desta natureza são bem-vindas e concorrem para melhorar o ambiente concorrencial e aperfeiçoar o sistema de contratação pública." ${ }^{30}$

Souza vai além e perfilha o entendimento de que sequer seria necessária legislação federal, estadual ou municipal a exigir programa de integridade nas licitações com a Administração Pública, pois, na sua opinião, a Constituição e a Lei n ${ }^{\circ} 12.846 / 2013$ já ofereceriam substrato para tanto.31_32

Que a evolução na implementação de programas de integridade nas empresas se daria muito mais rapidamente não parece haver dúvida. Seria ela, porém, oportuna? Os especialistas que discordam do dever, por imposição legal, de se ter programa de integridade para firmar contratos com o poder público se baseiam, basicamente, no tripé: efetividade, sistema de avaliação e transferência de custos.

Como cediço, os programas de integridade são deveras custosos. Por isso, uma obrigação de tão significativo impacto e reflexo nas operações cotidianas de inúmeras empresas pode vir a impulsionar o surgimento de programas de integridade "de fachada", isto é, que existem tão-só no papel para que a empresa possa contratar com a Administração Pública.

Daí a importância de um sistema de avaliação dos programas de integridade. Hodiernamente, esses programas são avaliados pontualmente, quer seja no momento em que a empresa voluntariamente o submete ao programa empresa pró-ética, referido alhures, quer seja quando a empresa invoca a sua existência para fins de cálculo na aplicação das sanções da Lei no 12.846/2013 (art. $7^{\circ}$, VIII c/c parágrafo único). A obrigatoriedade da existência de um programa de integridade para a celebração de contratos com a administração pública obviamente provocará um expressivo acréscimo na necessidade de avaliação desses programas, devendo o poder público estar pronto. Isso significa dizer que deve haver uma estrutura permanente e profissionais autônomos e capacitados para tanto. Nessa perspectiva, Costa aponta duas alternativas, que seriam a criação de uma agência anticorrupção, com estrutura e independência funcional e remuneração atraente para os seus membros, voltada à fiscalização das práticas anticorrupção e a concentração da avaliação dos programas de integridade em uma estrutura já existente, preferencialmente com profissionais independentes, técnicos no assunto e afeitos ao lido com a classe empresarial. Elegendo a última alternativa, a autora sugere o Conselho Administrativo de Defesa Econômica (CADE) para o ofício. ${ }^{33}$

Uma outra preocupação, ainda atinente aos custos de implantação desses programas nas empresas, é a de sua transferência para a administração pública. É o que certamente ocorrerá. Sobre o assunto, Souza acentua que, conquanto os custos sejam repassados ao poder público, ainda assim valerá a pena, pois os valores serão menos expressivos do que o que se perde com a corrupção nos dias atuais:

Ainda que as pessoas jurídicas incorram em custos com a implementação do programa de integridade e esses sejam repassados para as propostas e consequentes parcerias firmadas pela administração pública, esses gastos não se comparam aos elevados custos que a corrupção enseja para o Estado e para a

30 GUIMARÃES, Fernando Vernalha; REQUI, Érica Miranda dos. Exigência de programa de integridade nas licitações. In: PAULA, Marco Aurélio Borges de; CASTRO, Rodrigo Pironti Aguirre de (Org.). Compliance, gestão de riscos e combate à corrupcãa: integridade para o desenvolvimento. Belo Horizonte: Fórum, 201. p. 214.

31 Souza perscruta o cabedal principiológico da Constituição (partindo a sua análise de uma abrangência mais lato senso, de princípios como os do Estado Democrático de Direito e da dignidade da pessoa humana, até os princípios da Administração Pública), relacionando-o com os programas de integridade e a disciplina da Lei $n^{\circ} 12.846 / 2013$, para, ao final, sustentar a juridicidade da exigência de programa de integridade para participar de licitações e firmar contratos e outras parcerias com o Estado.

32 SOUZA, Horácio Mendes Augusto de. A juridicidade da exigência de programa de integridade para participar de licitações e firmar contratos e outras parcerias com o Estado. Revista da Procuradoria-Geral do Estado do Espírito Santo, Vitória, v. 15, n. 15, p. 166, 2017.

33 COSTA, Gabriela Revoredo Pereira da. Compliance, Lei da Empresa Limpa e Lei Sapin II: uma análise da aplicação do regime de obrigatoriedade de adoção de programas de integridade corporativa no Brasil. 2017. 111 f. Monografia (Graduação em Direito) Universidade Federal do Rio Grande do Norte, Natal, 2017. p. 88. 
sociedade, em desvios de vultosos recursos públicos, de modo que, se o programa de integridade efetivo contribuir para a redução da corrupção nas parcerias administrativas estatais, o eventual custo citado já estará mais do que justificado, sob a ótica dos princípios da razoabilidade, da proporcionalidade, eficiência e economicidade nas parcerias administrativas. ${ }^{34}$

Perpassadas as questões da constitucionalidade e da oportunidade de se exigir, por lei estadual, a implementação de programas de integridade nas empresas que firmarem contratos com a administração pública, a conclusão a que se chega é a de que, nada obstante a adoção desses programas pelas empresas que se relacionem com a Administração Pública em muito beneficiaria ela e a toda a sociedade (o que aqui não se discute), o ordenamento jurídico brasileiro dispõe de ferramentas outras, menos controversas (diferençadas do ato de pura e simplesmente exigir), das quais se pode fazer uso.

Uma política pública baseada em nudges, como a apresentada neste artigo, seguramente pode acelerar a implementação de programas de integridade nas empresas que com eles queiram se relacionar. Tudo isso de forma menos controversa, antipática e imposta — apesar de indiscutivelmente mais lenta. Há quem sustente, em matéria de licitação, inclusive, que a indução de condutas, ao revés de sua mera imposição, acaba por se mostrar ainda mais eficaz. A esse respeito, esclarecedora é a lição de Ferreira e Pottumati ao asseverar que:

em determinadas atividades e setores, o modelo de regulação que procura, ao invés de impor determinados padrões, induzir o comportamento do mercado em direção a práticas socialmente desejáveis, lançando mão de mecanismos de coordenação estratégica de interesses, pode revelar-se mais eficaz. De fato, a mera imposição de diretivas pode dificultar sua aceitação ou ser tão rigorosa a ponto de se tornar impraticável ou de difícil observância, enquanto que modelos menos invasivos são capazes de preservar, na maior medida possível, a liberdade de escolha, estabelecendo sistemas de incentivo que chamem o particular a colaborar. ${ }^{35}$

Dá-se a predileção em virtude de uma mudança de cultura, pospondo-se a pura e simples obrigatoriedade. É definitivamente o caminho mais longo a se percorrer.

\section{Considerações finais}

Há longos anos, o Brasil passa por problemas relacionados à corrupção e isto tem repercutido nos contratos, concessões e parcerias firmados pelo setor público. A implantação de programas de integridade nas empresas que contratassem com a Administração Pública em muito colaboraria com o enfrentamento desse problema.

Os programas de integridade abrangem uma série de mecanismos de conformidade e de integridade, a serem continuamente disseminados na empresa/entidade pública e auditados, bem como a aplicação de códigos de ética e de conduta, políticas e diretrizes sobre os mais diversos assuntos, objetivando prevenir irregularidades, fraudes e atos de corrupção praticados contra a Administração Pública, sem olvidar a detecção e a punição daqueles que, ainda assim, insistem na prática de tais atos.

Nesse contexto, não somente princípios diretamente relacionados à ética e à integridade no relacionamento com o poder público são concretizados como outros mais, a exemplo dos que possibilizam uma melhor gestão administrativa e econômica na Administração Pública.

Não obstante isso, a implantação de programas de integridade é custosa e, no mais das vezes, envolve alteração de toda uma cultura não apenas da empresa, mas do próprio ramo em que atua. Daí a extrema

34 SOUZA, Horácio Mendes Augusto de. A juridicidade da exigência de programa de integridade para participar de licitações e firmar contratos e outras parcerias com o Estado. Revista da Procuradoria-Geral do Estado do Espirito Santo, Vitória, v. 15, n. 15, p. 161, 2017.

35 FERREIRA, Felipe Furtado; POTTUMATI, Eduardo Carlos. A licitação pública como instrumento de desenvolvimento na perspectiva do paternalismo libertário. Revista Brasileira de Políticas Públicas, Brasília, v. 4, n. 1, p. 201-213, 2014. 
valia de uma política pública baseada em nudges para encorajar as empresas que projetam contratos com a Administração Pública a instituírem tais programas.

Sob essa ótica, nudge é a sutil interferência no comportamento de outrem, sem fazer uso de proibições, restrições ou vultosos incentivos financeiros, respeitando, assim, a sua liberdade de escolha. Centra-se no paternalismo libertário, segundo o qual ao poder público e instituições privadas é legítimo influenciar as escolhas das pessoas, guiando-as para uma vida mais longa, saudável e melhor, contanto que a liberdade delas seja preservada.

E como seria uma política pública de incentivo à implementação de programas de integridade para empresas que pretendam contratar com a Administração Pública baseada em nudges? Seis ideias foram lançadas. A primeira delas, a disponibilização na internet — se possível, no portal da transparência — de uma listagem com as instituições públicas e privadas que possuem contratos com a Administração Pública possuidoras de programas de integridade. Poder-se-ia, inclusive, ir além e relacionar aquelas que já tiveram os seus programas avaliados como efetivos pela Administração Pública. É, ressalte-se, basicamente o que tem sido feito no programa empresa Pró-Ética. Em segundo lugar, destacou-se a publicidade negativa resultado da condenação de uma empresa em atos de improbidade administrativa. Nesse contexto, vale registrar o Cadastro Nacional de Empresas Punidas (CNEP). A terceira ideia foi tornar acessível e de fácil compreensão não somente os custos associados à corrupção como a sua repercussão a nível de políticas públicas. Apesar de inúmeros estudos sobre a corrupção terem sido disponibilizados na internet para o acesso de quem sobre eles tiver interesse, o ritmo acelerado cotidiano nem sempre permite que as pessoas se inteirem de tudo o que as interessam e, sem informação, acabam não tendo reação. Daí o préstimo de se compilar e se transformar valores e percentuais em perdas concretas em políticas públicas. Alvitrou-se, em quarto lugar, a insertação da existência e aplicação de um programa de integridade como critério de pontuação em licitações que funcionam sob critérios de técnica e preço ou melhor técnica. Empós, sugeriu-se que a Administração Pública aclarasse o seu comprometimento com os planos de integridade e o enfrentamento da corrupção a partir não apenas da adoção, pelos próprios entes federados, de programas de integridade como da regulamentação da Lei no 12.846/2013 no âmbito dos Estados e Municípios.

Sucede que alguns Estados têm transposto o nudge com a publicação de legislações que obrigam, a depender do tipo e do valor do objeto/ serviço, a implementação de programas de integridade por empresas que com ele pretendem contratar. É o caso dos Estados do Rio de Janeiro (Lei estadual no 7.753/2017) e do Distrito Federal (Lei distrital no 6.112/2018).

Levando em consideração o art. 22, XXVII da Constituição, que atribui privativamente à União legislar sobre normas gerais de licitação e contratação para as administrações públicas diretas, autárquicas e fundacionais de todos os entes federados, o que dizer da constitucionalidade de dispositivo de lei estadual que impõe obrigações à contratação pública? Sobre o assunto, não há consenso.

Para os que consideram inconstitucional o dever, por imposição de lei estadual, de as empresas que contratarem com a Administração Pública implementarem programas de integridade, estaria o legislador estadual, ao fazê-lo, malferindo o art. 22, XXVII da Constituição. Isso porque sujeitar a contratação com o poder público, de maneira tão ampla, configuraria norma geral e uma que iria de encontro aos princípios da competitividade e da igualdade de condições entre os participantes de uma licitação pública.

Já os que o julgam constitucional, o fazem refutando definições muito amplas de normas gerais e argumentando a efetivação pelos referidos programas de um vasto cabedal de princípios valorizados pela Constituição da República, como os da impessoalidade, da moralidade administrativa, da publicidade, da eficiência, da economicidade, dentre outros.

O Supremo Tribunal Federal, ainda, não teve a oportunidade de se pronunciar sobre o assunto. Contudo, a Corte Constitucional, na ADI no $3.735 / \mathrm{MS}$, já se manifestou pela inconstitucionalidade da Lei $\mathrm{n}^{\circ}$ 3.041/2005, do Estado de Mato Grosso do Sul, que, apesar de não tratar especificamente do assunto das 
Leis $n^{\circ} 7.753 / 2017$, do Rio de Janeiro, e 6.112/2018, do Distrito Federal, exige documentação fora do art. 27 da Lei no 8.666/1993 para a contratação com o poder público estadual. Essa, aliás, é a dicção que se extrai de outros julgados do STF.

Ultrapassada a questão da constitucionalidade e considerando que a evolução na implementação de programas de integridade nas empresas se daria muito mais rapidamente com a exigência, seria ela oportuna? A doutrina contende.

Os especialistas que discordam do dever, por imposição legal, de se ter programa de integridade para firmar contratos com o poder público se baseiam, basicamente, no tripé: efetividade, arriscando o surgimento de programas "de fachada"; necessidade de se ter uma estrutura permanente e profissionais autônomos e capacitados para a avaliação dos programas de integridade; e transferência dos custos de implementação dos programas para as propostas e parcerias firmadas com a Administração Pública.

A conclusão a que se chega é a de que, nada obstante a adoção desses programas pelas empresas que se relacionem com a Administração Pública em muito beneficiaria ela e a toda a sociedade — o que aqui não se discute, o ordenamento jurídico brasileiro dispõe de ferramentas outras (diferençadas do ato de pura e simplesmente exigir), menos controversas, das quais se pode fazer uso.

Uma política pública baseada em nudges, como a apresentada neste artigo, seguramente pode acelerar a implementação de programas de integridade nas empresas que com eles queiram se relacionar. Tudo isso de forma menos controversa, antipática, imposta e, para alguns, até mais eficaz — apesar de indiscutivelmente mais lenta.

Dá-se a predileção é por uma mudança de cultura, pospondo-se a pura e simples obrigatoriedade. É definitivamente o caminho mais longo a se percorrer.

\section{REFERÊNCIAS}

BRASIL. Lei no 8.666, de 21 de junho de 1993. Regulamenta o art. 37, inciso XXI, da Constituição Federal, institui normas para licitações e contratos da Administração Pública e dá outras providências. Diário Oficial da União, Brasília, 22 jun. 1993. Disponível em: <http://www.planalto.gov.br/ccivil_03/Leis/18666cons. htm>. Acesso em: 20 maio 2018.

BRASIL. Lei n ${ }^{\circ}$ 12.846, de $1^{\circ}$ de agosto de 2013. Dispõe sobre a responsabilização administrativa e civil de pessoas jurídicas pela prática de atos contra a administração pública, nacional ou estrangeira, e dá outras providências. Diário Oficial da União, Brasília, 2 ago. 2013. Disponível em: <http://www.planalto.gov.br/ ccivil_03/_ato2011-2014/2013/lei/112846.htm>. Acesso em: 20 maio 2018.

BRASIL. Supremo Tribunal Federal. Ação Direta de Inconstitucionalidade. Constitucional e administrativo. Lei 3.041/05, do Estado do Mato Grosso do Sul. Licitações e contratações com o poder público. Documentos exigidos para habilitação. Certidão negativa de violação a direitos do consumidor. Disposição com sentido amplo, não vinculada a qualquer especificidade. Inconstitucionalidade formal, por invasão de competência privativa da União para legislar sobre a matéria (Art. 22, inciso XXVII, da CF). 1. A igualdade de condições dos concorrentes em licitações, embora seja enaltecida pela Constituição (art. 37, XXI), pode ser relativizada por duas vias: (a) pela lei, mediante o estabelecimento de condições de diferenciação exigíveis em abstrato; e (b) pela autoridade responsável pela condução do processo licitatório, que poderá estabelecer elementos de distinção circunstanciais, de qualificação técnica e econômica, sempre vinculados à garantia de cumprimento de obrigações específicas. 2. Somente a lei federal poderá, em âmbito geral, estabelecer desequiparações entre os concorrentes e assim restringir o direito de participar de licitações em condições de igualdade. Ao direito estadual (ou municipal) somente será legítimo inovar nesse particular se tiver como 
objetivo estabelecer condições específicas, nomeadamente quando relacionadas a uma classe de objetos a serem contratados ou a peculiares circunstâncias de interesse local. 3. Ao inserir a Certidão de Violação aos Direitos do Consumidor no rol de documentos exigidos para a habilitação, o legislador estadual se arvorou na condição de intérprete primeiro do direito constitucional de acesso a licitações e criou uma presunção legal, de sentido e alcance amplíssimos, segundo a qual a existência de registros desabonadores nos cadastros públicos de proteção do consumidor é motivo suficiente para justificar o impedimento de contratar com a Administração local. 4. Ao dispor nesse sentido, a Lei Estadual 3.041/05 se dissociou dos termos gerais do ordenamento nacional de licitações e contratos, e, com isso, usurpou a competência privativa da União de dispor sobre normas gerais na matéria (art. 22, XXVII, da CF). 5. Ação direta de inconstitucionalidade julgada procedente. Procurador Geral da República. Governador do Estado do Mato Grosso do Sul e outro. Relator: Ministro Teori Zavascki. Brasília, 08 de set. de 2016. Diário Oficial da União, Brasília, 2016.

BRASIL. Supremo Tribunal Federal. Ação Direta de Inconstitucionalidade. Direito Administrativo e Constitucional. Lei no 11.871/02, do Estado do Rio Grande do Sul, que institui, no âmbito da Administração Pública Regional, preferência abstrata pela aquisição de softwares livres ou sem restrições proprietárias. Exercício regular de competência legislativa pelo Estado-membro. Inexistência de usurpação de competência legiferante reservada à União para produzir normas gerais em tema de licitação. Legislação compatível com os princípios constitucionais da separação dos Poderes, da impessoalidade, da eficiência e da economicidade. Pedido julgado improcedente. 1. A competência legislativa do Estado-membro para dispor sobre licitações e contratos administrativos respalda a fixação por lei de preferência para a aquisição de softwares livres pela Administração Pública regional, sem que se configure usurpação da competência legislativa da União para fixar normas gerais sobre o tema (CRFB, art. 22, XXVII). 2. A matéria atinente às licitações e aos contratos administrativos não foi expressamente incluída no rol submetido à iniciativa legislativa exclusiva do Chefe do Poder Executivo (CRFB, art. $61, \$ 1^{\circ}$, II), sendo, portanto, plenamente suscetível de regramento por lei oriunda de projeto iniciado por qualquer dos membros do Poder Legislativo. 3. A Lei n $11.871 / 2002$ do Estado do Rio Grande do Sul não engessou a Administração Pública regional, revelando-se compatível com o princípio da Separação dos Poderes (CRFB, art. $\left.2^{\circ}\right)$, uma vez que a regra de precedência abstrata em favor dos softwares livres pode ser afastada sempre que presentes razões tecnicamente justificadas. 4. A Lei $n^{\circ} 11.871 / 2002$ do Estado do Rio Grande do Sul não exclui do universo de possíveis contratantes pelo Poder Público nenhum sujeito, sendo certo que todo fabricante de programas de computador poderá participar do certame, independentemente do seu produto, bastando que esteja disposto a celebrar licenciamento amplo desejado pela Administração. 5. Os postulados constitucionais da eficiência e da economicidade (CRFB, arts. 37, caput e 70, caput) justificam a iniciativa do legislador estadual em estabelecer a preferência em favor de softwares livres a serem adquiridos pela Administração Pública. 6. Pedido de declaração de inconstitucionalidade julgado improcedente. DEMOCRATAS. Governador do Estado do Rio Grande do Sul e outro. Relator: Ministro Ayres Britto. Brasília, 09 de abril de 2015. Diário Oficial da União, Brasília, 2015.

BRASIL. Tribunal de Contas da União. Referencial de combate à fraude e corrupção: aplicável a órgãos e entidades da Administração Pública. 2017. Disponível em: < http://portal.tcu.gov.br/biblioteca-digital/referencialde-combate-a-fraude-e-corrupcao.htm>. Acesso em: 28 maio 2018.

COSTA, Gabriela Revoredo Pereira da. Compliance, Lei da Empresa Limpa e Lei Sapin II: uma análise da aplicação do regime de obrigatoriedade de adoção de programas de integridade corporativa no Brasil. 2017. 111 f. Monografia (Graduação em Direito) - Universidade Federal do Rio Grande do Norte, Natal, 2017.

DALLARI, Adilson Abreu. Aspectos jurídicos da licitação. 6. ed. Rio de Janeiro: Saraiva, 1999.

FEDERAÇÃO DAS INDÚSTRIAS DO ESTADO DE SÃO PAULO (FIESP). Corrupcão: custos econômicos e propostas de combate. 2010. Disponível em: <https://www.google.com.br/url?sa=t\&rct=j\&q=\&esr $\mathrm{c}=\mathrm{s} \&$ source $=$ web\&cd $=1 \&$ ved $=0$ ahUKEwiTiPXCxaTbAhWMfZAKHZJNCj0QFggnMAA\&url=http $\% 3$ A $\% 2 \mathrm{~F} \% 2 \mathrm{Fwww}$.fiesp.com.br\%2Farquivo-download $\% 2 \mathrm{~F} \% 3 \mathrm{Fid} \% 3 \mathrm{D} 2021 \&$ usg=AOvVaw3nuNdZSkRM1 WIFoJrzc3Up>. Acesso em: 26 maio 2018. 
FERREIRA, Felipe Furtado; POTTUMATI, Eduardo Carlos. A licitação pública como instrumento de desenvolvimento na perspectiva do paternalismo libertário. Revista Brasileira de Políticas Públicas, Brasília, v. 4, n. 1, p. 201-213, 2014.

FONSECA, Antonio. Programa de Compliance ou Programa de Integridade: o que isso importa para o direito brasileiro?. In: LAMBOY, Christian K. de (Org.). Manual de Compliance. São Paulo: Instituto Arc, 2017.

GUIMARÃES, Fernando Vernalha; REQUI, Érica Miranda dos. Exigência de programa de integridade nas licitações. In: PAULA, Marco Aurélio Borges de; CASTRO, Rodrigo Pironti Aguirre de (Org.). Compliance, gestão de riscos e combate à corrupção: integridade para o desenvolvimento. Belo Horizonte: Fórum, 2018.

JUSTEN FILHO, Marçal. Comentários à lei de licitaçoes e contratos administrativos. 15. ed. São Paulo: Dialética, 2012.

MELLO, Celso Antônio Bandeira de. Curso de Direito Administrativo. 11. ed. São Paulo: Malheiros, 1999.

NASCIMENTO, Juliana Oliveira. Panorama internacional e brasileiro da governança, riscos, controles internos e compliance no setor público. In: PAULA, Marco Aurélio Borges de; CASTRO, Rodrigo Pironti Aguirre de (Org.). Compliance, gestão de riscos e combate à corrupcão: integridade para o desenvolvimento. Belo Horizonte: Fórum, 2018.

PINHO, Clóvis Alberto Bertolini de. É preciso cautela ao exigir compliance em contrato público. Revista Consultor Jurídico, 2018. Disponível em: < https://www.conjur.com.br/2018-fev-18/clovis-pinho-precisocautela-compliance-contrato-publico>. Acesso em: 28 maio 2018.

ROSE-ACKERMAN, Susan. Corruption: a study in political economy. New York: Academic Press, Inc., 1978.

ROSE-ACKERMAN, Susan. Corruption and government: causes, consequences, and reform. Cambridge: Cambridge University Press, 1999.

RIO DE JANEIRO. Lei no 7.753, de 17 de outubro de 2017. Dispõe sobre a instituição do programa de integridade nas empresas que contratarem com a administração pública do Estado do Rio de Janeiro e dá outras providências. Diário Oficial do Estado do Rio de Janeiro, 18 out. 2017.

SOUZA, Horácio Mendes Augusto de. A juridicidade da exigência de programa de integridade para participar de licitações e firmar contratos e outras parcerias com o Estado. Revista da Procuradoria-Geral do Estado do Espirito Santo, Vitória, v. 15, n. 15, p. 143-169, 2017.

THALER, Richard H.; SUSTEIN, Cass R. Nudge: improving decisions about health, wealth, and happiness. New York: Penguin Books, 2009.

ZAGANELLI, Juliana Costa; MIRANDA, Wallace Vieira de. Marco civil da internet e política pública de transparência: uma análise da e-democracia e do compliance público. Revista Brasileira de Políticas Públicas, Brasília, v. 7, n. 3, p. 633-646, 2017. 
Para publicar na revista Brasileira de Políticas Públicas, acesse o endereço eletrônico www.rbpp.uniceub.br

Observe as normas de publicação, para facilitar e agilizar o trabalho de edição. 